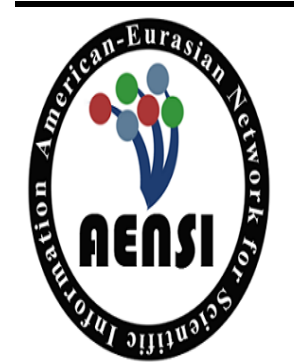

AUSTRALIAN JOURNAL OF BASIC AND APPLIED SCIENCES

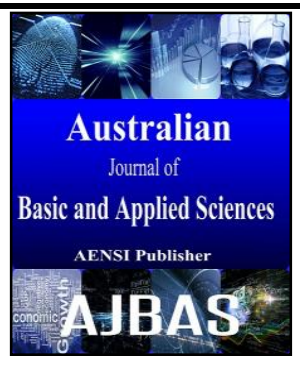

\title{
The relationship between administrative corruption and organizational factors Study on workers in the Ministry of Health Libya
}

\author{
${ }^{1}$ Mari Abdulsalam Hassan, ${ }^{2}$ Asbi B. Ali, ${ }^{3}$ Faraj S Gab Alla \\ ${ }^{1,2,3}$ college of Management Business, Management and Science University(MSU), Malaysia
}

\author{
Address For Correspondence: \\ Mari Abdulsalam Hassan, Management and Science University (MSU), college of Management Business, 40150 Shah Alam, Selangor, \\ Malaysia.
}

\section{ARTICLE INFO}

\section{Article history:}

Received 12 October 2017

Accepted 22 November 2017

Available online 6 December 2017

Keywords:

Administrative

bribery,favoritism

factors. corruption,

Organizational

\begin{abstract}
A B S T R A C T
Bbackground: Administrative corruption is an international phenomenon that can be monitored in all communities no matter what the geographical location is. Organizational factors inciting corruption in the Benghazi city health sector in Libya will be known through this study. This study also defines the organizational factors relation with the administrative corruption manifestations, and indicates the intensity of spread of these manifestations. Objectives: This study aimed to achieve an overall objective to identify the organizational factors that cause the phenomenon of corruption spread in Libyan society and to study the most remarkable negative effects of this phenomenon to the economy and administration. It also aimed on working to estimate the incidence of corruption in the case study area of the society and indicate the most important shapes or pictures, the most widespread administrative corruption study society, as well as identify the factors causing vast administrative corruption and the most important organizational factors and its influential role on the administration and the staff. The most important organizational variables are inefficient leadership (scientifically and artistically and technically), instability and persistent change in the restructure of administration, managers and administrators, weak oversight and performance. Evaluation systems and multiple devices are also trying to determine the relationship between organizational factors and the presence of manifestations of administrative corruption and in addition, by analyzing the Health Ministry staff opinion. Findings: This research was conducted among all employees of the Benghazi Ministry of Health in which 1,500 employees were randomly selected. About 300 questionnaires were distributed to the respondentsand the analysis wasdone using the SPSS statistical analysis software. The result of thisresearchrevealed that the Benghazi health sector is inundated with theadministrative corruption manifestations. Its prevalence and manifestations were mainly from the perspective of the study due to favoritism and financial allocationsloss that is granted to operating hospitals in the Benghazi city. Moreover, it stunsfrom official transactions and certificates forgery as well as forgery of patients medical reports, fictitious projects sub-substandard specifications, duplication of work among some doctors, nurses and technicians in the public and private sectors, weakening of the primary health care, funds and drugs shortage as well as the inadequacy of medical supplies. Conclusion: Decision makers can benefit from this paper for should continuous development of anti-corruption laws and legislation ensuring firmly appropriate penalties on every perpetrator without favor or exception. Based on the work of the studied objectives, competent laws of various regulatory bodies should be enacted to rid the sector of duplication or repetition and the proposal to amend their laws and methods of work to not be an impediment to the work of the administrative oversight. Putting a right person in a right position and accordance to eligibility, qualification and experience with review of his performance will help curb the menace of administrative corruption.
\end{abstract}

Open Access Journal

Published BY AENSI Publication

(C) 2017 AENSI Publisher All rights reserved

This work is licensed under the Creative Commons Attribution International License (CC BY).

http://creativecommons.org/licenses/by/4.0/ 


\section{INTRODUCTION}

Corruption is a global phenomenon prevalent in all human societies; both developed and developing. The phenomenon has recently increased in developing countries making them fertile environment to grow. It grows rapidly in environments where democratic governance is lacking and that there is no transparency as they require constant monitoring for ensuring efficient administrative performance of organs, as there have not been proportionality rules in the income per capita for individuals, the requirements and needs of life that entice public and private employees in resorting to illegal ways to acquire material (Jassim2009).

Studies showed that the collapse of many Libyan economic institutions was as a result of the big first place, manifestations and effects of financial and administrative corruption and failure to embrace the curriculum right for administrative reform. Thishas ranked Libyathe third in the Arabian states ranking of financial and administrative corruption in 2013. It istherefore necessary to learn the major underlying causes of the corruption phenomenon in the administrative, demographic factors and management from the perspective of the researcher(Tamimi2012).

In view of the above, the problem summarizes the lack of successful solutions before the Libyan officials to reduce the rampant corruption in government hospitals and public clinics. Herein, the administrative corruption will be examined and the concept of administrative corruption will be learnt that the corruption spread significantly in the Benghazi health sector.

In addition, the search problem in answer to the following questions can be determined:

1. What are the major factors that lead to administrative corruption in the Benghazi health sector?

2. What constitutes the variables for organizational and personal factors and the manifestations of administrative corruption in the Benghazi health sector in Libya?

\section{Literature Review:}

Corruption is a deviant behaviour occurring in administrative work settings ofpublic sector, of which the perpetrator(mostly employee) does it with a view to achievingpersonal interests, whether materialistic or otherwise, alone or jointly with others inside or outside the organization, considering its patterns of behaviour such as top of form, bribery, exploitation and mutuality of interests and undue benefits, fraud, forgery, extortion,mediation and nepotism in the appointment of relatives and friends or in the distribution of administrative and social services, embezzlement, cashing in bonuses and rewards outstanding administrative actions, exemption from services fees and taxes (Dahesh 2013).

The quality of services rendered by administrative organs of various countries affected is in compliance with the ethics of public employee group and functional behaviors, as carrying the burdens of administrative bodies. This tasks for serving the citizens and ensures administrative development programs thereby necessitating it to have a range of broad powers and rationalizing budgets of large financial credit in which it is regrettable that this is done without enabling them to build the administrative apparatus, proper construction and development capabilities and fortifying against possibilities, deviation, exploitation or be subject to follow-up and control (Zewail2006).

As leaving administrative arms acting with public monies and funds without accountability or proper supervision is regarded as financial and administrative corruption, then the more the expansion of decisionmaking authority for employees the greater rates unethical activities and abuse of power and hence, the more the increase in administrative corruption cases. The increase in this is of concern to the citizenry, and the administrative organs in this view yields a tyrant in power, in spite of the fact that the more established rules of the public servants must be equality and justice in their dealings for the benefits of public services (Albaba2012).

It has been found out by a researcher that there exist many cases of financial and administrative corruption, cronyism and loss of financial allocations granted to hospitals in Libya hospitals. There have also been cases of duplication of work among some doctors and nurses and staff in the public and private sector coupled with work neglect in the public sector and loss of control of private clinics and pharmacies which resulted in many negative phenomena such as the sale of the medicine at high prices and sale of expired medicines. There has also been non-compliance with specifications and technical assets that are essential for the implementation of projects of the Libyan health ministry.

Moreover, health care has been weakened leading to shortage of medicines and medical supplies, especially emergency stocks and chemical solutions which opened the market for smuggling, causing the inability of citizens to obtain them. There have also been some reported negative aspects such as lack of respect for punctuality to work.

In 2011, Libyan health sector suffereda widespread administrative corruption, and despite the success of the revolution and the overthrow of the former regime, Libya still ranked 168th among 183 corrupt countries. This therefore means that there has been an increase in corruption which preparesto cripple the new construction phase of the nationfor achieving economic development to the desired levels. In the same 2011, there was a 
load treatment for diabetics, transferred from west to east during the period of the revolution. Before the liberation of Tripoli under the auspices of the health committee in Benghazi, almost about 200 thousand dinars had been stolen in the road during transport (Almadani2006).

In Tripoli, the Wounded Affairs commission, an independent body specialized in treating the woundedrebels was established. However, this body has referred all patients for treatment abroad without agreement with local hospitals and without considering the availability of treatment in those countries (Kilani2014).

In January/February 2012, the number of Libyans in Turkey on behalf of war wound from 2011 reached 17 thousand while the number of supervisors and administrators, doctors and accountants was only 250. It was noted that the current cases involving cases of infertility, dentistry, ophthalmology, plastic surgery in general, in addition to the hardship cases such as amputation, reported to hospitals for long periods, involved big money pending contract with the competent authorities for treatment(Dahesh2013).

In April 2012, the Minister of health presented a report about some errors discovered in scanning in health clinics and hospitals registered with the Libyan health ministry, for the assessment of the injury suffered after the revolution, and then locate the coordinates. The team was sent for examination, where the survey found out that more than $3 \%$ of the registered health facilities of the ministry did not physically exist. They were either desert or closed dispensary followingverification by the department and it has been shown that they have financial staff and regular salaries and budget have been acted uponby the health ministry (Matar2011).

The ministry of health in the year 2014 announced tender worth one billion dinars for the supply of medicines in full rather than supply each month, resorted to unify in one bid to coincide with the dearth of financial accounts. The administrative control authority tried suspending this contract due to the suspicion of the existence of administrative corruption and Mali in the way of the contract (Al-hamroush2013).

In 2015, the commission chairman disposed of expired medicines to the ministry of health. About 100,000 tons of expired medicines had been available in the stores of Libyan hospitals since these drugs include "special drugs to tumor diseases, acquired immune deficiency syndrome (AIDS), diabetes, asthma and other diseases. This call for a question to answer about why the accumulation of expired drugs due to a conflict in formatting, random importation of medicines without knowing its listings and quantities as well as what causes the accumulation of drugs without need. On why the drugs are imported by hospitals directly, and not through the ministry, a study entitled financial and administrative corruption, its causes and how it could be eliminated, how is corruption in our country and who are corrupt, in 2013 was conducted. It showed that administrative corruption as a systematic phenomenon under the old regime was thought that it would help prolong the system by tempting system officials at the highest levels and push them to indulge in financial and moral corruption.

Of the most important reasons for the spread of administrative corruption is a big difference between working state employees' salaries of workers in companies and institutions of strategic importance such as postal company, telecommunications, electricity and oil companies, cement, maritime transport and ports. The salaries of the workers in other sectors and on the same career became very low when compared and therefore the workers resorted to corrupt practices such as the signing of suspicious transactions and corrupt contracts in order to get huge salaries(Al-Khamisi2012).

This is in addition to other privileges to some actors such as health insurance and free treatment in private clinics or abroad and the rest of the staff were being treated as second class citizens and therefore are not entitled to what they are entitled to. Resource control has become state decisions to increase their salaries, with some actors increasing the salaries of their members taking advantage of some influence in the state administration(Khribish2013).

There is also a study entitled "corruption plagues the Libyan health sector" in 2015, which states that the Libyan health sector suffered neglect, lack of experienced staff and equipment in public hospitals, which forced the citizens to look for treatment abroad for surgery. This is as a result of one's fear of medication, negligence and lack of equipment which leaves no choice although the private clinics were not better than public hospitals, lacking equipment and techniques, but it is a solution for those who could not travel outside and on the reasons behind the deterioration in the health sector. The study observed that the main reason was that hospitals and health centres did not have budgets; the Ministry of health hospital supplies were not diverted to any appropriations, and thus had stopped working, to the extent that there was no special budget by the ministry since 2013. This was due to the lack of a budget approved by the legislature. Things are taking place in the ministry automatically supported on the previous inventory of drugs and devices provided by the previous budgets (Bin lamh2015).

There are four factors affecting the prevalence of corruption in organization:

First: double control systems and performance evaluation, and the multiplicity of existing devices. The lack of oversight; that is the inability of holding an employee for unwanted actions done while having complete power to do so. This has really stimulated a number of staff in public offices to breach trust of the public by acting in an unfair way and illegally. Deviant practices are encouraged by some managers due to lax oversight in accounting staff delinquents and overlook of malpractice. In view of the above, it can be concluded that lack of 
oversight and weakness allow for the spread of deviant practices of corruption in organizations which makes the public staff desperate to acquire illegal earning by whatever way possible, as there exist a misconception that that is the only way for survival. This is an indication that poor control and inspection are vital in increasing the incidence of corruption in organizational settings in which the officials of the public service enjoy power without restriction or control (Khamis 2014).

Existence of multiple regulatory bodies affects significantly the fight corruption in administration. Individual exercise of activity without coordination among the bodies only wastes public money and time. Moreover nepotism in employment and treatment also hampers the fight against corruption (Mohamed2005).

Various reports in Libya indicated the existence of multiple of regulatory bodies that overlap power and jurisdiction. These numbered up to more than six supervisory bodies exercising control over the body of public institutions. This creates confusion in the government of the Libyan state.

More studies revealed a lot of weaknesses in the control of the Benghazi health ministry administration. The researcher assumed that there was a significant statistical relation between the weak control systems and performance evaluation, and the multiplicity of existing devices and between them there exist features of corruption in Libyan administration.

Secondly, administrative instability and constant change of structure and managers also leads to the prevalence of corruption in Libya (Musa 2006).

As a process that is dynamic, a change requires a plan that is long-term in nature. This plan should comprehensively and accurately be implemented to achieve a modernity and originality balance and can be achieved only through the improvement of the human element via selection, preparation and training, rights and duties in the career path from the beginning to the end of service. (Hill 2006).

Thirdly, responsibilities distribution if abused leads to the emergence of corrupt practices. This is a style that compromises the upper and lower management in the act of supporting each other for problem solving. Here, power is the divided between the levels of administration.

Frequent changes in the Libyan administrative environment ranging from the first provincial systemto the municipal system sequel to the adoption of the popular system since 2000, through to the February Revolution in 2011 led to cancelled events and policies. This must have had a negative effect on the administration because of new laws and rules (Al Bayati2008). Social confusions and weaknesses in the management of staff lead to behavioural deviations from the law. The researcher made an assumption that there was a significant statistical relation between the lack of stability in administration and constant structural, managerial, administrative and official changes.

Lastly, the weakness of the efficiency of the administrative leadership; where a leader or manager fails to exercise his effective and efficient administrative duty as a result of external interference or pressure, loss of influence in which the staff feel that the leaders shy away from regulations and laws application, then corruption will likely come to exist. Moreover, when the manager or leader is keen on public fund or money then administration will have its den (Matar2011).

\section{Methodology:}

Descriptive and analytical approach to the subject of the study was applied. The reason for applying this approach is that applied in many research studies in the field of administrative and financial corruption, especially that research that involves illegal practices in business environments and organizations. In this approach, accurate information is collected in an orderly way, organized and categorized. Data are analyzed for results, interpreted and appropriate conclusions and generalizations are drawn. The study includes several important complementary aspects as follows:

First aspect:This aspect involves the use of books, periodicals and previous researches that are relevant to the subject of the for study purpose of configuring an appropriate conceptual framework for this study.

Second aspect: the field side. This includes data compilation through the questionnaire form from side of the crisis for access to information that represents the scientific aspect which through which hopefully the desired goals of the study were achieved.

Third aspect: the analytical side. This involves data analysis of the obtained information from the questionnaire form using appropriate statistical methods.

Fields of study:

The study areas involved the spatial and temporal domain of the human race. The study geographical scope is the Benghazi city in Libya, North Africa. The country Libya is bordered to the North by the Mediterranean Sea, to the East by Egypt, Sudan, Chad, Niger, Algeria and by Tunisia to the West. It has an area of 1750000 square kilometers.

The human field involved general workers in the Libyan state of Benghazi; employees and their monthly salaries from the state treasury in the health sector male or female, or young or old, except for pensioners and the disabled, workers and non-Libyan staff, while the time domain is the period from the time of Libyan political change in 2011 to the end of this research writing in 2016. 


\section{A community study:}

The total sample size was determined (1500) in the employee table according to Krejcie and Morgan (1970), which was employed to determine the sample optimum size on the basis of the size of the community. The study population size was 1500 employees, and thus the optimum sample size was 300 of which if the representation is calculated it would almost give $20 \%$ which is an acceptable representation considering the societal homogeneity and the small size and potential physical and the research devoted time. After selecting the sample size, a visit to the Benghazi hospitals and the health sector was conducted with distribution of forms to the staff such as doctors, technicians and the workers in hospital pharmacies. For the avoidance of bias and objectivity, the sample selection method was adopted. The form also included two parts: Part I identified the staff demographic characteristics. This included gender, age/length of service, income level. Other part II of the form includes two questions. The first question was on the measurement of the organizational factors/variables and this measure consists of (19) the words crafted likert Quintet, which enabled the determination of the extent of approval or disapproval on all questions on a scale in accordance with the gradient $(\mathrm{OK}, \mathrm{OK}, \mathrm{OK}$, somewhat disagree, strongly disagree).

The second question was for the identification of administrative corruption manifestations in Libyan environment in whicha measure of the manifestations of administrative corruption was obtainedthrough questions in a likertscale fashion.

The dependent variables (shown) and indicators:

The dependent variable employed in this study was administrative corruption is an illegal behavior by public officials on duty or outside office hours that were associated with corruption. Firstly, patronage and financial allocations granted for hospitals operating in the city of Benghazi. Another variable was the forging of official transactions, certificates and patients' medical. Phantom ventures were also considered, and this involved receiving some substandard for specifications and technical assets. The next one was duplication of work among some doctors and nurses in the public and private sectors and lastly, a weak primary health care and the shortage of vaccines, medicines and medical supplies for the emergency stockpile, and chemical solvents.

\section{RESULTS AND DISCUSSIONS}

\section{Descriptive analysis:}

Descriptive analysis was based on the description of the demographic variables on the study sample members as respondents. This was collected through the identification of the study based on the following descriptive analysis results of individuals under study:

Table 1: Number and percentage based on sex of the study population

Table 1: Number and percentage based on sex of the study population
\begin{tabular}{|c|l|l|l|}
\hline S/No & Sex & The number & Percentage $(\%)$ \\
\hline 1 & Males & 217 & 72.3 \\
\hline 2 & Females & 83 & 27.7 \\
\hline & Total & 300 & 100 \\
\hline
\end{tabular}

Table 2: The numbers and proportions of age groups in the sample study population

\begin{tabular}{|l|l|l|l|}
\hline S/No & Age group (years) & Number of Staff & Percentage (\%) \\
\hline 1 & less than 30 & 37 & 12.3 \\
\hline 2 & $30-39$ & 133 & 44.3 \\
\hline 3 & $40-49$ & 90 & 30.0 \\
\hline 4 & 50 and above & 40 & 13.3 \\
\hline
\end{tabular}

Form 2 illustrates the proportions of age groups sample study and is represented in Table 2 which shows that the range of age group of 30 to 39 years having the largest presence in the study sample by $44.3 \%$, followed by the age group (from 40 to 49 years) with $30 \%$ and a comparable age (less than 30 years) with $12 \%$. The age group 50 and abovehad only $13 \%$.

The next analysis was educational level, which showed the numbers and proportions of the educational levels of the members of the study sample population

Table 3: Educational levels of the member of the sample population

\begin{tabular}{|c|l|l|l|}
\hline S/N & Education level & Number of Staff & Percentage (\%) \\
\hline 1 & High school & 36 & 12.0 \\
\hline 2 & Diploma & 58 & 19.3 \\
\hline 3 & Collectors or equivalent & 166 & 55.3 \\
\hline 4 & Master & 26 & 14.7 \\
\hline 5 & Doctorate & 14 & 4.7 \\
\hline
\end{tabular}


Form (3) illustrates the proportions of academic qualifications for the study sample members which are also represented by Table 3 . It can be clearly observed that the educational level (University or equivalent) had the highest rate among members of the study sample having 55\%. The rest of educational levels had lower prevalence where the level of education for diploma was $19 \%$, high school or less $12 \%$, master's degree $9 \%$ and finally the highest educational level, PhDwith only $5 \%$.

Practical experience was also analyzed and the occurrence can be seen represented in the table below

Table 5: Number and proportions of the study sample members by practical experience

\begin{tabular}{|c|c|c|c|}
\hline S/N & $\begin{array}{c}\text { Practical experience } \\
\text { (years) }\end{array}$ & Number of Staff & Percentage (\%) \\
\hline 1 & Less than 1 year & 23 & 7.7 \\
\hline 2 & 3 & 43 & 14.3 \\
\hline 3 & $4-6$ & 50 & 16.7 \\
\hline 4 & $7-9$ & 85 & 28.3 \\
\hline 5 & 10 and above & 99 & 33.0 \\
\hline
\end{tabular}

Table 5above shows the respondents with practical experience of 10 years and above had the largest proportion of $33 \%$ which is followed by those with experienceof 7 to 9 yearswith $28 \%$ occurrence. Those with experienceof 4 to 6 years had a proportion of $17 \%$ and the experience of those with 1 to 3 years proportion was $14 \%$ and finally, $8 \%$ of the respondents had experienceof less than a year.

\section{Reliability factor:}

There are a number of statistical methods to measure the consistency and the most and which they can measure the steadiness is the method (Cronbach's alpha) which depend on the internal consistency and give an idea about the consistency of questions with each other and with all questions in General, and to verify the consistency of the answers to the questionnaire study was based on stability analysis method of Cronbach's alpha and table 1 shows the results of this test.

\begin{tabular}{|l|l|c|c|}
\hline & Organizational factors & $\begin{array}{c}\text { Number of } \\
\text { paragraphs }\end{array}$ & $\begin{array}{c}\text { Reliability } \\
\text { factor: }\end{array}$ \\
\hline 1 & of weak leadership efficiency scientifically and artistically & 6 & \\
\hline 2 & Managementinstability and constant change of structure and managers & 6 & 0.915 \\
\hline 3 & The weakness of the existing laws and administrative control and instrumentation & 7 & 0.773 \\
\hline 4 & Administrative corruption & 5 & 0.869 \\
\hline \multicolumn{2}{|l|}{ Reliability factor: } & 24 & 0.821 \\
\hline
\end{tabular}

To calculate the Validity statistical criteria. By the following equation:

$$
\begin{aligned}
& \mathrm{V}=\sqrt{S} \\
& \mathrm{~V}=\text { Validity } \\
& \mathrm{V}=.954
\end{aligned}
$$

\section{The first axis: axis of weak leadership efficiency scientifically and artistically:}

This link contains a questionnaire of 6 paragraphs and the objectivewas to examine the current situation of weak leadership efficiency axis reality scientifically and artistically andthis was obtained from the staffviewpoint in the Ministry of health and the table (8) shows the direction of the sample's views about this axis backbone.

Table (8): direction of the sample views around the axis of weak leadership efficiency scientifically and artistically and technically.

Table (8): the direction of the views of the sample around the axis of the weakness of the efficiency of the administrative leadership scientifically, technically and technically

OK, Strongly Disagree, Neutral, Disagree, Disagree strongly weighted average \%

The questions are as follows:

\begin{tabular}{|l|l|l|l|l|l|l|}
\hline The questions & $\begin{array}{l}\text { OK } \\
(\%)\end{array}$ & $\begin{array}{l}\text { Strongly } \\
\text { Disagree } \\
(\%)\end{array}$ & $\begin{array}{l}\text { Disagree } \\
(\%)\end{array}$ & $\begin{array}{l}\text { Neutral } \\
(\%)\end{array}$ & $\begin{array}{l}\text { Agree } \\
(\%)\end{array}$ & $\begin{array}{l}(\%) \\
\text { Managers work with non-specialist in Management }\end{array}$ \\
\hline Officials do not important goals of institutions & 5.3 & 48.0 & 7.0 & 36.0 & 4.7 & 3.4 \\
\hline More officials working with them were ineligible & 5.3 & 46.3 & 37.3 & 7.0 & 4.3 & 3.41 \\
\hline
\end{tabular}




\begin{tabular}{|l|l|l|l|l|l|l|}
\hline $\begin{array}{l}\text { Health officials don't care about justice and equity among } \\
\text { staff }\end{array}$ & 5.0 & 42.7 & 41.7 & 5.7 & 5.0 \\
\hline $\begin{array}{l}\text { Most managers and officials want to achieve personal } \\
\text { benefits to them }\end{array}$ & 4.7 & 45.3 & 40.7 & 5.3 & 4.0 \\
\hline Emergence of the phenomenon of mediation & 5.0 & 44.3 & 41.3 & 5.3 & 4.0 \\
\hline Overall average & \multicolumn{3}{|c|}{3.40} & 3.41 \\
\hline
\end{tabular}

The overall average was 3.40 seen from the table 8 the weighted average of the answers to the sample on the axis of the weakness of the efficiency of the administrative leadership scientifically and technically according to Eckart scale illustrated by table (8) to the weighted average of the Health Ministry staff answers on weak leadership efficiency scientifically and artistically as a scale likart Quintet was generally refers to the approval which shows that respondents ' views about the direction the axis trending positive and clearly confirms that the total weighted hub and who was (3.40) is implies also that means that there's a weakness in leadership efficiency scientifically and artistically and technically in the health sector in Libya according to respondents.

\section{The second axis: axis management instability and constant change of structure and managers:}

Majority of the changes that occurred in the Libyan sector of health were unplanned and negative. They were also improvisational. The changes were unnecessary and caused chaos. The changes equally do not serve the overall objectives of the health sector.

Changes occurred to benefit a small number of populations in Libya leading to administrative chaos which in turn led to illegal activities during work thereby giving room to administrative corruption.

\begin{tabular}{|c|c|c|c|c|c|c|}
\hline The questions & $\mathrm{OK}(\%)$ & $\begin{array}{l}\text { Strongly } \\
\text { Disagree } \\
(\%)\end{array}$ & $\begin{array}{l}\text { Disagree } \\
(\%)\end{array}$ & $\begin{array}{l}\text { Neutral } \\
(\%)\end{array}$ & $\begin{array}{l}\text { Agree } \\
(\%)\end{array}$ & $(\%)$ \\
\hline $\begin{array}{l}\text { Most of the changes that have taken place in the Ministry } \\
\text { of Health were negative and unplanned. }\end{array}$ & 4.3 & 55.0 & 29.3 & 6.0 & 5.3 & 3.47 \\
\hline $\begin{array}{l}\text { Most of the changes that have occurred in the health sector } \\
\text { was improvised. }\end{array}$ & 9.3 & 46.3 & 30.3 & 6.0 & 8.0 & 3.43 \\
\hline $\begin{array}{l}\text { Changes that occurred were the cause of chaos at work and } \\
\text { unnecessary. }\end{array}$ & 3.7 & 61.7 & 27.7 & 2.7 & 4.3 & 3.58 \\
\hline $\begin{array}{l}\text { The changes that have occurred in the Department } \\
\text { of health does not serve the overall objectives of the } \\
\text { Ministry }\end{array}$ & 6.0 & 49.7 & 31.7 & 4.0 & 8.7 & 3.40 \\
\hline $\begin{array}{l}\text { Changes that have occurred in the Ministry of Health } \\
\text { carried out by beneficiaries of people change. }\end{array}$ & 5.3 & 50.0 & 33.0 & 3.7 & 8.0 & 3.41 \\
\hline $\begin{array}{l}\text { Administrative chaos leads to illegal methods to work with } \\
\text { the Ministry of health }\end{array}$ & 5.3 & 50.0 & 33.0 & 3.7 & 8.0 & 3.41 \\
\hline Overall average & \multicolumn{6}{|c|}{3.48} \\
\hline
\end{tabular}

Illustrated by table (9) the weighted average of the sample answers the administrative instability axis and constant change to just likart scale directors structural Quintet was generally referred to the approval which shows that respondents' opinions on administrative instability and constant change of structural andmanagers tend to confirm this positive overall weighted to the axis, which was 3.48 is implied also approve this means that there is an administrative instability and also there is a continual change of structural health sector managers Libya According to respondents.

\section{The weakness of the existing laws and administrative control and instrumentation:}

There are enforced laws and regulations in the health sector whichfavor some employees to pass illegal transactions. The procedures of administration and finance in the health sector have not been well controlled. One may think that the law does not exist in most health sector departments.It has been very easy to evade the law and justiceas lawyers help immensely in any problem that is financial or administrative.

The lack of clarity of laws and regulations within the organization and exploitation of laws and regulations in the interest that is personal tosome officials. There is also lack of regulations and laws and also lack of will to encourage and protect employees who contribute to the detection of administrative corruption, not to expedite the investigation and trial of cases of administrative corruption 


\begin{tabular}{|c|c|c|c|c|c|c|}
\hline The questions & OK $(\%)$ & $\begin{array}{l}\text { Strongly } \\
\text { Disagree } \\
(\%)\end{array}$ & $\begin{array}{l}\text { Disagree } \\
(\%)\end{array}$ & $\begin{array}{l}\text { Neutral } \\
(\%)\end{array}$ & $\begin{array}{l}\text { Agree } \\
(\%)\end{array}$ & $(\%)$ \\
\hline $\begin{array}{l}\text { There are inthe law and regulations of the Ministry of } \\
\text { Health opportunities for some employees used to carry } \\
\text { out illegal transactions. }\end{array}$ & 3.0 & 54.0 & 28.3 & 6.0 & 8.7 & 3.37 \\
\hline $\begin{array}{l}\text { Administrative and financial procedures in the Ministry } \\
\text { of health is not well controlled }\end{array}$ & 5.3 & 41.0 & 34.0 & 6.0 & 13.7 & 3.18 \\
\hline $\begin{array}{l}\text { The law does not apply in most of the departments of } \\
\text { the Ministry of Health }\end{array}$ & 2.3 & 53.0 & 31.7 & 4.0 & 9.0 & 3.36 \\
\hline $\begin{array}{l}\text { Easy escape from the law. Because lawyers can } \\
\text { assist with any administrative or financial problem. }\end{array}$ & 6.3 & 54.7 & 27.3 & 4.3 & 7.3 & 3.48 \\
\hline $\begin{array}{l}\text { The lack of clarity of laws and regulations within the } \\
\text { Ministry of Health, and the exploitation of laws and } \\
\text { regulations for personal interests }\end{array}$ & 2.7 & 51.3 & 34.3 & 3.0 & 8.7 & 3.36 \\
\hline $\begin{array}{l}\text { The lack of laws and regulations for encouraging and } \\
\text { protecting employees who contribute to the detection of } \\
\text { corruption. }\end{array}$ & 8.7 & 51.3 & 29.3 & 4.3 & 6.3 & 3.52 \\
\hline $\begin{array}{l}\text { Not to expedite investigation and prosecution in cases of } \\
\text { administrative corruption }\end{array}$ & 3.0 & 50.0 & 26.7 & 4.0 & 16.3 & 3.19 \\
\hline Overall average & \multicolumn{6}{|c|}{3.35} \\
\hline
\end{tabular}

Illustrated by a table 10, the weighted average of the sample answers on weak laws and administrative control systems as a scale likart Quintet was generally refers to neutrality where respondents answers averages in most of the paragraphs of this axis. Less than 3.40 indicate that respondents' opinions on weak laws and administrative control systems are obviously close to neutrality and confirm that the total weighted centrewas 3.35. It also signifies neutrality too meaning that the opinions of the respondents' diverged on regulation concerning weak laws and administrative control systems in the generality of Libyan health sector. Paragraph 4 was an exception. Thisprovides easy way to get away with the law that lawyers can help you with any administrative or financial problem as well as paragraph 6 , which provides lack of regulations and laws protecting employees who contributed in exposing corrupt practices. Where there was clear agreement among the respondents, the average answers to each paragraph were 3.48 and 3.52 .

\section{Axis of administrative corruption:}

This encompasses nepotism and the loss of financial allocations granted to Benghazi hospitals, official certificates and transactionsfalsification (contracts, invoices and financial receipts), forgery of official transactions and certificates (contracts and invoices and fiscal receipts, scientific instruments and certificates and medical reports for patients), fictitious projects, or receiving substandard technical assets and specifications in the implementation of project in the sector of health. It also involves the duplication of work among some doctors, nurses and technicians in both private and public sectors, weakening primary health care and the shortage of funds and medicines, medical supplies, causing an open market and traded on the black market.

\begin{tabular}{|c|c|c|c|c|c|c|}
\hline The questions & $\mathrm{OK}(\%)$ & $\begin{array}{l}\text { Strongly } \\
\text { Disagree } \\
(\%)\end{array}$ & $\begin{array}{l}\text { Disagree } \\
(\%)\end{array}$ & $\begin{array}{l}\text { Neutral } \\
(\%)\end{array}$ & $\begin{array}{l}\text { Agree } \\
(\%)\end{array}$ & $(\%)$ \\
\hline $\begin{array}{l}\text { Nepotism and the loss of financial allocations granted to } \\
\text { hospitals operating in the city of Benghazi }\end{array}$ & 1.7 & 45.3 & 42.3 & 3.3 & 7.3 & 3.31 \\
\hline $\begin{array}{l}\text { Falsification of official transactions and scientific } \\
\text { certificates and medical reports for patients }\end{array}$ & 3.0 & 47.0 & 36.3 & 3.0 & 10.7 & 3.29 \\
\hline $\begin{array}{l}\text { The establishment of phantom projects. Or delivery of } \\
\text { projects without the required technical specifications and } \\
\text { asset level for the implementation of the Ministry of Health } \\
\text { Projects }\end{array}$ & 1.3 & 43.7 & 38.0 & 6.3 & 10.7 & 3.19 \\
\hline $\begin{array}{l}\text { Duplication of work among some doctors, nurses and } \\
\text { technicians the public and private sectors }\end{array}$ & 1.7 & 39.7 & 32.3 & 7.3 & 19.0 & 2.98 \\
\hline $\begin{array}{l}\text { Weak primary health care, lack of medicines and medical } \\
\text { supplies }\end{array}$ & 2.7 & 32.0 & 41.0 & 6.7 & 17.7 & 2.95 \\
\hline Overall average & & & 3.14 & & & \\
\hline
\end{tabular}

Illustrated by table (11) the weighted average of the sample answers corruption as a scale likert Quintet was generally referred to neutrality where respondents answers averages over most of the paragraphs of this axis less than 3.40 which shows that respondents' opinions on administrative corruption is clearly geared for neutrality and confirms that the total weighted hub was 3.14 andthis implies neutrality. Itequally means that respondent ' 
opinions diverged on regulationsconcerning the axis of administrative corruption in the generality of Libyan health sector.

\section{Correlation analysis:}

Spearman's correlation coefficient was employed to determine the relationship between the study axes and the strength and impact of the studied parameters. According to statistical rules, the following were deduced:

\section{The relationship between the weak efficiency of the administrative leadership scientific and technical and administrative corruption:}

In the relationship between weak leadership efficiency scientifically, artistically and technically and administrative corruption as mentioned earlier, the Spearman correlation coefficient was used in determining the strength of the relationship between weak axis leadership efficiency scientifically and artistically and technically and axis of administrative corruption andTable 12 displays the results of the test.

Table 12: Spearman correlation coefficient of the relationship between weak leadership efficiency scientifically, artistically and technically and administrative corruption

\begin{tabular}{|l|l|l|}
\hline Relationship & Spearman Coefficient & Level indication \\
\hline $\begin{array}{l}\text { Double the efficiency of administrative leadership x } \\
\text { administrative corruption }\end{array}$ & 0.401 & $\mathrm{P}=0.00$ \\
\hline
\end{tabular}

It can be seen from the above table that the Spearmancorrelation coefficient was 0.401 which indicates a positive relationship between twice the efficiency of administrative leadership and administrative corruption. This means that the more the weak leadership efficiency scientifically, artistically and technically the more the administrative corruption and this is confirmed by the level of significance $(0.000)$ that is less than 0.05 and hence there is a statistical function that shows the impact of weak leadership competence on administrative corruption.

However, the correlation coefficient (0.401) conclusively shows a good relationshipvalue between the two variables.Thisindicates that administrative corruption is directly and clearly proportional to the poor leadership competency.

Moreover, the table below shows the preliminary results of simple linear regression analysis of the relationship between administrative corruption and poor efficiency of the administrative leadership.

Table 13: Simple correlation coefficient

\begin{tabular}{|l|l|l|l|l|}
\hline $\begin{array}{l}\text { simple } \\
\text { coefficient }\end{array}$ & R selection coefficient & $\begin{array}{l}\text { R debugger coefficient } \\
\text { of determination }\end{array}$ & $\begin{array}{l}\text { value alpha } \\
\mathrm{f}\end{array}$ & significance level \\
\hline 0.401 & 0.161 & 0.158 & 0.094 & 0.00 \\
\hline
\end{tabular}

The table above shows the simple correlation coefficient $(\mathrm{R})$ havingthe value of 0.401 . The selection coefficient of 0.161 and the debugger selection 0.158 this indicates that the focus of administrative corruption is affected. This includes a rate of $16.10 \%$ twice the efficiency of administrative leadership and the rest, with many other reasons.

The table also shows that the level of significance $\mathrm{P}=0.00$ for the analysis of test variance in terms of value indicates alpha $\mathrm{F}$ to the high presence of moral confirm the high explanatory model simple linear regression test relying on the simple linear regression test results and strong and Table 14 shows the rest of the test results.

\section{The relationship between the lack of administrative stability and constant change of structure, managers and administrative corruption:}

Spearmancorrelation coefficient was also used in determining the strength and type of the relationship between the axis of lack of administrative stability and constant change of structure, managers and the focus of administrative corruption. Table 15 below displays the results of the analysis.

Table 15: Spearman correlation coefficient between the lack of administrative stability and constant change of structure, managers and administrative corruption

\begin{tabular}{|l|l|l|}
\hline relationship & Spearman coefficient & Level of significance \\
\hline $\begin{array}{l}\text { lack of administrative stability and constant } \\
\text { change for structural and managers } \\
\times\end{array}$ & 0.320 & 0.00 \\
administrative corruption & & \\
\hline
\end{tabular}

It can be seen from the above table that Spearman correlation coefficient is 0.320 indicating a positive relationship between the lack of administrative instability and constant change of structure, managers and 
administrative corruption. In this sense, the greater the lack of administrative stability and constant change for structural and managers the greater the administrative corruption and that significance level $(\mathrm{P}=0.000)$ which is less than 0.05 signifying statistically significant relationship that shows the impact of lack of administrative stability by the constant change for structural and managers on administrative corruption

Ensuring the results of this test link, simple linear regression was testedin which corruption is influenced by administrative instability and constant change of structure and managers in addition to the relationship between the type and strength of trusts. Table (16) shows the preliminary results of a simple linear regression of this relationship.

Table 16: Preliminary results of the test of simple linear regression displaying relationship between corruption and administrative instability and constant change of structural and managers

\begin{tabular}{|l|l|l|l|l|}
\hline $\begin{array}{l}\text { Simple correlation } \\
\text { coefficient }\end{array}$ & $\begin{array}{l}\text { Coefficient of } \\
\text { determination R }\end{array}$ & $\begin{array}{l}\text { selection coefficient } \\
\text { debugger }\end{array}$ & $\begin{array}{l}\text { value alvaaeh } \\
\text { F }\end{array}$ & level indications \\
\hline 0.320 & 0.103 & 0.100 & 34.107 & 0.00 \\
\hline
\end{tabular}

The table above shows the correlation coefficient $(\mathrm{R})$ which was $0.320,0.103$ selection coefficient and coefficient of determination 0.100 debugger. This indicates that the focus of administrative corruption is influenced by $10.30 \%$ axis of administrative instability and continuous managers and structural changes.

\section{The relationship between the weakness of the laws and administrative control systems and administrative corruption:}

Spearmancorrelationcoefficient was also employedin determining the type and strength of the relationship between the axis of the weakness of the laws and administrative systems of control and the administrative corruptionfocus. Table 18 displays the test results.

Table 18: Spearman correlation coefficient between poor law and management control systems and administrative corruption

\begin{tabular}{|l|l|l|}
\hline Relationship Spearman coefficient & & Level of significance \\
\hline $\begin{array}{l}\text { relationship Spearman coefficient } \\
\text { significance level of weak laws and } \\
\text { management control systems } \\
\times \text { administrative corruption }\end{array}$ & 0.397 & $\mathrm{P}=0.00$ \\
\end{tabular}

It can also be seen from the table above that there was a Spearmancorrelation coefficient of 0.397indicating positive relationship of proportionality between the weakness of the laws and systems of administrative control and administrative corruption. Thismeans that the weaker the laws and systems of administrative control, the more the corruption in administration, and this confirms the significance level of $\mathrm{P}=0.000$ which is less than 0.05 indicating statistically significant differencein the impact of weak laws and Administrative control over the system of administrative corruption.

An inference can be deduced from the correlation coefficient of 0.397 that the strength of the relationship value represents a good relationship between the two variables. Thissimply means that administrative corruption is vividly directly influenced by weak laws and administrative control systems.

Table 19: Simple linear regression test of the relationship between administrative corruption and weak laws and administrative control

\begin{tabular}{|l|l|l|l|l|}
\hline $\begin{array}{l}\text { Simple value alvaaeh } \\
\text { coefficient }\end{array}$ & $\begin{array}{l}\text { Coefficient of level indications } \\
\text { determination R }\end{array}$ & $\begin{array}{l}\text { selection coefficient } \\
\text { debugger }\end{array}$ & vation \\
\hline 0.397 & 0.157 & 0.154 & 55.632 & 0.00 \\
\hline
\end{tabular}

The above table shows that administrative corruption focus is influenced by $15.70 \%$ administrative oversight laws weak axis and the rest see for other reasons.

Conclusions and recommendations:

The results of the study confirmed widespread manifestations of administrative corruption in the health sector in the Libyan city of Benghazi. Furthermore, the corrupt practices in the health sector ranged from the commonest from interviewees' points of view such as favoritism and loss of granted financial allocations to the operating hospitals Benghazi in Benghazi city. Certificates and official transactions forgery were also found to have been rampant, thereby increasing the prevalence of administrative corruption. There were also phantom ventures or receipt of substandard specifications and technical assets in the implementation of the health sector projects.

Moreover, work duplication was rampant among many doctors, nurses and technicians within the private and public sectors. In addition, there was poor primary health care and the shortage of funds and medicines, 
medical supplies. Finally, relationship between these factors and the manifestations of administrative corruption was analyzed using Jackson Pearson coefficient of a relationship.

Recommendations

In addition, the role of the judiciary should be maintainedand so shall be their independence and integrity and should notat all be subjected to external pressure, which may add difficulties in the detection and accountability involved in the cases of corruption.To avoid the establishment of phantom projects recognized contractors and the internationally recognized companies should be contacted and appropriate agreement should be reached on how to receive allocations of projects.For more safety, the full amount of money should not be paid to the companies in cash in the first instance.

Finally, further study on the relationship between organizational factors and administrative corruption in the health sector of the Libyan Benghazi city should be encouraged so that authorities concern will know and be serious, as eyes are on them. The studies should include the legal, political and economic factors which may be among the causes of corruption in the work environment of all sectors, and not limited to only health care.

\section{REFERENCES}

Al Bayati, F., 2008. Economic development in the Arab world. Doctoral dissertation in economics. Arabic open. Academy in Denmark. Oman

Albaba, M., 2012. The relationship between environmental factors and administrative corruption.

Al-hamroush, F., 2013. A report of the Ministry of Health of the Transitional Government regarding the wounded.

Al-Khamisi, A., 2012. Administrative oversight "stop a billion dinars for the Ministry of health. http://www.alwasat.ly/ar/news/liby.

Almadani, N., 2006. The relationship between the factors Altnzimiho administrative corruption.

Bin lamh, W., 2015. Corruption eats away the Libyan health sector, the new Arab magazine, Tripoli.

Dahesh, R., 2013. "From Bouazizi to Bab Azizia", Tripoli. www.goodreads.com/author/show.

Dahesh, R., 2013. Bouazizi to azizia, Tripolitania. www.goodreads.com/author/show.

Hill, R., 2006. Administrative corruption. Strategic management journal

Jassim, M., 2009. Corruption between transparency and tyranny (1rd ed). Dania press: Baghdad.

Khamis, A., 2014. "Administrative Control. Magazine center Gate.

Khribish, M., 2013. Financial and administrative corruption, (its causes and how it can be eliminated). Who spread corruption in our country and those who are corrupt. Al-Watan newspaper Libya.

Kilani, N., 2014. File corruption" threatens the health system in Libya. ww.skynewsarabia.com/web/article.

Matar, E., 2011. Administrative corruption is, its causes, manifestations (1 $\mathrm{rd} \mathrm{ed}$ ), Dar University: Alexandria.

Matar, E., 2011. administrative corruption is, its causes, manifestations (1 $\mathrm{rd}$ ed), Dar University: Alexandria.

Mohamed, N., 2005. Administrative control in the case study of government institutions (Ministry of Health and the state of Khartoum from 1993 to 2003). University of Khartoum.

Musa, J., 2006. Organizational culture and change management. University House: Alexandria.

Tamimi, A., 2012. Governance mechanisms and role in reducing corruption in State-owned companies' alaadar. http://www.academia.edu/16670319.

Zewail, H., 2006." administrative corruption and its relationship to the sociological study of social change at the Egyptian post-1970 what society needs" University of Arts Alaxanderahklah, PhD thesis. 